\title{
Prevalence of serological markers of hepatitis B virus in pregnant women from Paraná State, Brazil
}

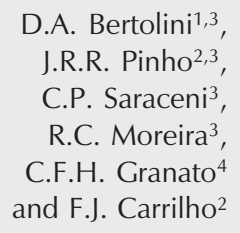

\author{
${ }^{1}$ Laboratório de Imunologia Clínica, Departamento de Análises Clínicas, \\ Universidade Estadual de Maringá, Maringá, PR, Brasil \\ ${ }^{2}$ Departamento de Gastroenterologia, Instituto de Medicina Tropical, \\ Faculdade de Medicina da Universidade de São Paulo, São Paulo, SP, Brasil \\ ${ }^{3}$ Serviço de Virologia, Instituto Adolfo Lutz, São Paulo, SP, Brasil \\ ${ }^{4}$ Disciplina de Doenças Infecciosas e Parasitárias, Escola Paulista de Medicina, \\ Universidade Federal de São Paulo, São Paulo, SP, Brasil
}

\section{Correspondence \\ J.R.R. Pinho \\ Instituto de Medicina Tropical \\ Av. Dr. Enéas de Carvalho Aguiar, 470 \\ 05508-000 São Paulo, SP \\ Brasil \\ Fax: +55-11-3064-5132 \\ E-mail: jrrpinho@usp.br}

Research supported by FAPESP (No. 99/04455-1) and Alves de Queiroz Family Fund for Research. Q. . . . .

Received September 20, 2005 Accepted May 12, 2006

\begin{abstract}
The prevalence of hepatitis B virus (HBV) in Brazil increases from South to North but moderate to elevated prevalence has been detected in the Southwest of Paraná State. The prevalence of serological markers of HBV was evaluated in 3188 pregnant women from different counties in Paraná State and relevant epidemiological features were described. The prevalence of HBV markers in pregnant women for the state as a whole was $18.5 \%(95 \% \mathrm{CI}=17.2-19.9)$, ranging from $7.2 \%$ in Curitiba to $38.5 \%$ in Francisco Beltrão. The endemicity of $\mathrm{HBV}$ marker prevalence in pregnant women was intermediate in Cascavel, Foz do Iguaçu, and Francisco Beltrão, and low in Curitiba, Londrina, Maringá, and Paranaguá. Multiple logistic regression showed that HBV marker prevalence increased with age, was higher among black women, among women of Italian and German descent, and among women who had family members in neighboring Rio Grande do Sul State. Univariate analysis showed that HBV marker prevalence was also higher among women with no education or only primary education, with a lower family income and whose families originated from the South Region of Brazil. Pregnant women not having positive HBV markers (anti-HBc, HBsAg or anti-HBs detected by ELISA) corresponded to $73.7 \%$ of the population studied, implying that HBV vaccination needs to be reinforced in Paraná State. The highest prevalence was found in three counties that received the largest number of families from Santa Catarina and Rio Grande do Sul, where most immigrants were of German or Italian ascendance. This finding probably indicates that immigrants that came to this area brought HBV infection to Southwestern Paraná State.
\end{abstract}

\section{Introduction}

Hepatitis B virus (HBV) infection is a worldwide public health problem affecting about 350 million people (about $5 \%$ of the
Key words

- Hepatitis B virus

- Brazil

- Serological markers

- Pregnant women

................ human population). Most of these individuals can transmit the disease without knowing that they are infected. Furthermore, some develop severe chronic liver disease (1).

In some regions of the world, e.g., sub- 
Saharan Africa, more than half of the population becomes HBV infected during their lifetime and more than $8 \%$ of inhabitants become chronic carriers. In these regions, most infections take place during delivery or infancy. In North and West Europe, North America and Australia, chronic HBV carriers are found in less than $2 \%$ of the population and HBV infection generally occurs in young adults by sexual transmission or occupational exposure (2). In Latin America, there are more than 140,000 acute cases per year and about 6.6 to 12 million people are chronic HBV carriers. More than $65 \%$ of these cases live in South America, where about 100,000 cases of acute hepatitis B occur annually, and the overall prevalence of HBV infection in low-risk populations ranges from 6.7 to $41 \%$ while $\mathrm{HBs} A g$ rates range from 0.4 to $13 \%$ (3).

In Brazil, there are more than 75,000 acute cases per year and HBsAg prevalence increases from South to North: $1 \%$ in South and Central West regions; 2\% in Southeast region; $2.5 \%$ in Northeast region, and $8 \%$ in North region (3). Moderate to elevated HBsAg prevalence has been detected in candidate blood donors from the West region of Santa Catarina $(4.3 \%)$ and Paraná $(8.3 \%)$ States (4).

According to the WHO classification of the endemicity of HBV infection, Paraná State is a low-endemicity area (5). Previous data have shown that the prevalence in this state is lower than in other Brazilian regions, such as the Amazon basin $(4,6)$ and some areas of Espírito Santo State (7), and similar to that of other states, such as São Paulo, Rio Grande do Sul, and Ceará $(4,8)$.

In general, Southern Brazil is a lowendemicity area (4,9-11). However, some areas in Southern Brazil have been recently reported to have moderate HBV prevalence, such as some regions of Western Santa Catarina and Paraná States. In Paraná, the prevalence of HBsAg is higher in the counties of Francisco Beltrão, Cascavel (12), and
Chapecó $(8.3,3.8$, and $4.3 \%$, respectively) (4).

The aim of the present study was to evaluate the prevalence of HBV infection among pregnant women from different counties of Paraná State and to describe relevant epidemiological features found in the infected population.

\section{Material and Methods}

\section{Study area}

As shown in Figure 1, Paraná State is located in the South of Brazil, just below São Paulo State. From 1850 to the middle of the 20th century, Paraná State attracted immigrants from different countries, especially Italy, Germany, Poland, Ukraine, Netherlands, Spain, and Japan. The latest census, performed in 2000, showed a population of $9,563,485$ inhabitants with the following color distribution: $77.0 \%$ whites, $4.0 \%$ blacks, $1.3 \%$ Asians, $17.2 \%$ mulattos, and $0.2 \%$ Indians. As shown in Figure 1, for this protocol, we chose to analyze 7 different counties covering different areas of this state: Paranaguá, Curitiba, Londrina, Maringá, Cascavel, Foz do Iguaçu, and Francisco Beltrão.

\section{Population}

Blood samples were collected from 3188 pregnant women ranging in age from 12 to 44 years (mean \pm SD: $24.2 \pm 6.2$ ) registered in the Public Prenatal Service between May 1998 and May 2002, from the following counties: Cascavel $(\mathrm{N}=496)$, Curitiba $(\mathrm{N}=$ 458), Foz do Iguaçu $(\mathrm{N}=505)$, Francisco Beltrão $(\mathrm{N}=442)$, Londrina $(\mathrm{N}=335)$, Maringá $(\mathrm{N}=379)$, and Paranaguá $(\mathrm{N}=$ 573).

The Ethics Committees of Instituto Adolfo Lutz and Universidade Federal de São Paulo approved this study and each pregnant woman gave written informed con- 
sent before sample collection. The women were also interviewed for collection of data such as age, color (13), educational level (according to the Brazilian Ministry of Education levels), family income, ancestral descent, and internal migration (other Brazilian regions or South region states).

\section{Serology}

All blood samples were tested for HBsAg, anti-HBs and total anti-HBc using ELISA tests (DiaSorin S.p.A., Saluggia, Italy) and an ETI-STAR automatic microplate analyzer (Diasorin). Samples were considered to be positive when the OD/CO (sample optical density/assay cut off) ratio was higher than 1.1. Samples with initial results in the gray zone $(0.9<\mathrm{OD} / \mathrm{CO}<1.1)$ were retested and, if this result persisted, they were excluded from this study.

\section{Statistical analysis}

The dataset was organized and analyzed using the Epi-Info program, version 6.0. Statcalc and Epitables applications were used for chi-square and confidence interval (CI) analysis, respectively (14), with the level of significance set at $\mathrm{P}<0.05$. Significant variables in univariate analysis were then used to adjust a multiple logistic regression model with a stepwise procedure to select variables using the Statistical Package for Social Sciences (SPSS) software, version 12.0, for Windows (15). The model was shown in a table containing the estimated parameters, standard error, significance probability, odds ratio, and the respective $95 \% \mathrm{CI}$.

\section{Results}

The prevalence of pregnant women from Paraná State with serological markers for past or present $\mathrm{HBV}$ infection (i.e., anti-HBc and/or HBsAg positive) analyzed in this study was $18.5 \%(591 / 3188)(95 \% \mathrm{CI}=17.2-19.9)$. In $133(4.2 \%)$ anti-HBc-positive samples, HBsAg and anti-HBs were not detected. HBsAg was found in 54 (1.7\%) women, including 5 samples without detectable anti$\mathrm{HBc}$. Three other samples $(0.1 \%)$ were simultaneously reactive for the 3 markers.

For individual counties, the highest preva-

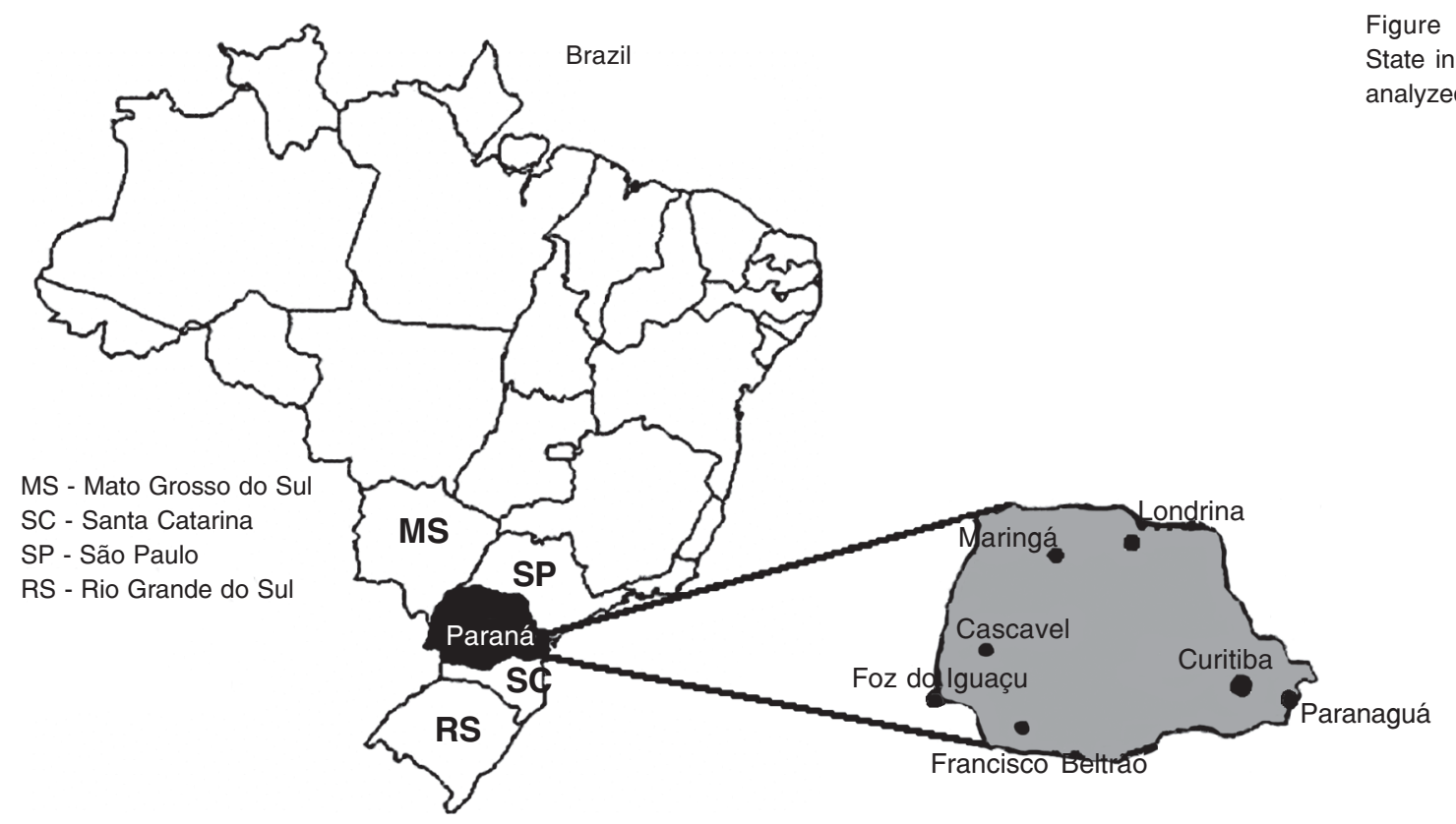

Figure 1. Location of Paraná in Brazil and the counties nalyzed in the present study. 
lence (i.e., frequency of anti-HBc- and/or HBsAg-positive pregnant women) was found in Francisco Beltrão (38.5\%) and the lowest in Curitiba (7.2\%). Prevalence was also higher in Foz do Iguaçu (24.6\%) and Cascavel $(24.0 \%)$ when compared to the other counties analyzed.

As a measure of $\mathrm{HBV}$ vaccination coverage, the prevalence of isolated anti-HBs was 7.7\%. Francisco Beltrão and Cascavel showed the highest frequency of isolated anti-HBs-carrying women (17.3 and $12.5 \%$, respectively). The other five counties studied showed at most only $5.5 \%$ of anti-HBscarrying women. Except for Francisco Beltrão, more than $50 \%$ of pregnant women from the other counties showed no serological HBV marker (Table 1).

The results of univariate analysis of the features of pregnant women and their relation to HBV status are shown in Table 2. As expected, the prevalence of serological HBV markers increased with age, with the frequency increasing from 8.7 in women younger than 20 years to $50.7 \%$ in women older than 30 years $(\mathrm{P}<0.001)$. Serological HBV markers were also more frequent in black women $(24.3 \%)$ than in the other groups, in women with no education $(20.3 \%)$ or with only primary education $(20.7 \%)$, and in women with a lower family income $(20.5 \%)$ - $\mathrm{P}<0.05$. Women belonging to families of Italian or German ancestry showed a higher frequency of HBV markers $(\mathrm{P}<0.05), 26.3$ and $30.4 \%$, respectively. Families of these two origins were especially common in Francisco Beltrão and the frequency of $\mathrm{HBV}$ markers was also higher in women belonging to these families (data not shown). Family internal migration data showed that only women from families originating from the South Region had a statistically significant higher risk of HBV infection $(20.2 \% ; \mathrm{P}<0.05)$. Further analysis involving only South region states demonstrated that women from families migrating from Rio Grande do Sul State had a higher risk of hepatitis B infection (37.0\%) than families from the other two States, Paraná and Santa Catarina $(\mathrm{P}<0.05)$.

The results of multivariate analysis are shown in Table 3. Age, black color, family origin from Italy and Germany, and internal migration from Rio Grande do Sul State

Table 1. Prevalence of serological markers for past or present HBV infection, isolated anti-HBs and susceptible pregnant women from Paraná State (1998 to 2002).

\begin{tabular}{|c|c|c|c|c|c|c|c|c|c|}
\hline \multirow[b]{4}{*}{ County } & \multirow[b]{4}{*}{$\mathrm{N}$} & \multicolumn{6}{|c|}{ Serological profile for past or present HBV infection } & \multirow{4}{*}{$\begin{array}{c}\text { Anti-HBs } \\
\text { isolated }\end{array}$} & \multirow{4}{*}{$\begin{array}{l}\text { Absence of HBV } \\
\text { serological makers: } \\
\text { anti-HBc (-) } \\
\text { HBsAg (-) } \\
\text { anti-HBs (-) } \\
\mathrm{N}(\%)\end{array}$} \\
\hline & & \multicolumn{3}{|c|}{ Anti-HBc $(+)$} & \multirow{3}{*}{$\begin{array}{c}\text { Anti-HBc (-) } \\
\text { Anti-HBs (-) } \\
\text { HBsAg (+) } \\
\mathrm{N}(\%)\end{array}$} & \multirow{2}{*}{\multicolumn{2}{|c|}{ Total }} & & \\
\hline & & $\mathrm{HBsAg}(+)^{*}$ & Anti-HBs (+) & Anti-HBs (-) & & & & & \\
\hline & & $\mathrm{N}(\%)$ & $N(\%)$ & $N(\%)$ & & $\mathrm{N}(\%)$ & {$[95 \% \mathrm{IC}]$} & & \\
\hline Cascavel & 496 & $7(1.4 \%)$ & $85(17.1 \%)$ & $27(5.4 \%)$ & $0(0.0 \%)$ & 119 (24.0\%) & [20.3-28.0] & $62(12.5 \%)$ & $315(63.5 \%)$ \\
\hline Curitiba & 458 & $3(0.7 \%)$ & 26 (5.7\%) & 4 (0.9\%) & 0 (0.0\%) & 33 (7.2\%) & {$[5.1-10.1]$} & $22(4.8 \%)$ & 403 (88.0\%) \\
\hline Foz do Iguaçu & 505 & $7(1.4 \%)$ & $90(17.8 \%)$ & $27(5.3 \%)$ & $0(0.0 \%)$ & $124(24.6 \%)$ & [20.9-28.6] & $25(4.9 \%)$ & $356(70.5 \%)$ \\
\hline Francisco Beltrão & 442 & $17(3.8 \%)$ & $112(25.3 \%)$ & $38(8.6 \%)$ & $3(0.7 \%)$ & $170(38.5 \%)$ & {$[33.9-43.2]$} & $77(17.3 \%)$ & $195(44.1 \%)$ \\
\hline Londrina & 335 & $2(0.6 \%)$ & $30(9.0 \%)$ & $11(3.3 \%)$ & $0(0.0 \%)$ & $43(12.8 \%)$ & {$[9.5-17.0]$} & $17(5.1 \%)$ & $275(82.1 \%)$ \\
\hline Maringá & 379 & $7(1.8 \%)$ & $20(5.3 \%)$ & $13(3.4 \%)$ & $1(0.3 \%)$ & $41(10.8 \%)$ & [7.9-14.5] & $21(5.5 \%)$ & $317(83.6 \%)$ \\
\hline Paranaguá & 573 & $6(1.0 \%)$ & $41(7.2 \%)$ & $13(2.3 \%)$ & $1(0.2 \%)$ & $61(10.6 \%)$ & [8.3-13.5] & 22 (3.8\%) & 490 (85.5\%) \\
\hline Total & 3188 & $49(1.5 \%)$ & 404 (12.7\%) & $133(4.2 \%)$ & $5(0.2 \%)$ & $591(18.5 \%)$ & [17.2-19.9] & $246(7.7 \%)$ & $2351(73.7 \%)$ \\
\hline
\end{tabular}


Table 2. Characteristics of pregnant women and their relation to the prevalence of HBV serological markers by univariate analysis.

\begin{tabular}{|c|c|c|c|c|}
\hline & $\mathrm{N}^{\mathrm{a}}$ & HBV positive N (\%) & HBV negative $\mathrm{N}(\%)$ & $P$ \\
\hline Age (years) & 2842 & & & \\
\hline$<20$ & 859 & $75(8.7 \%)$ & 784 (91.3\%) & $<0.001$ \\
\hline $20-29$ & 1634 & $326(20.0 \%)$ & $1308(80.0 \%)$ & \\
\hline$>30$ & 349 & 177 (50.7\%) & $172(49.3 \%)$ & \\
\hline Color & 3057 & & & \\
\hline White & 2393 & $434(18.1 \%)$ & 1959 (81.9\%) & \\
\hline Black & 288 & 70 (24.3\%) & $218(75.7 \%)$ & $<0.05$ \\
\hline Indian & 15 & $2(13.3 \%)$ & $13(86.7 \%)$ & \\
\hline Mulatto & 349 & 69 (19.8\%) & $280(80.2 \%)$ & \\
\hline Asian & 12 & 0 & $0(100.0 \%)$ & \\
\hline Educational level & 3135 & & & \\
\hline No education & 64 & $13(20.3 \%)$ & $51(79.7 \%)$ & \\
\hline Fundamental & 1987 & 412 (20.7\%) & 1575 (79.3\%) & $<0.05$ \\
\hline Medium & 987 & 145 (14.7\%) & $842(85.3 \%)$ & \\
\hline Superior & 97 & 15 (15.5\%) & $82(84.5 \%)$ & \\
\hline Family income $(x \mathrm{MW})^{\mathrm{b}}$ & 3062 & & & \\
\hline$<2$ & 1212 & 249 (20.5\%) & 963 (79.5\%) & $<0.05$ \\
\hline $2-5$ & 1634 & $286(17.5 \%)$ & $1348(82.5 \%)$ & \\
\hline$>5$ & 216 & 34 (15.7\%) & $182(84.3 \%)$ & \\
\hline Ancestral descent & 3046 & & & \\
\hline Brazilian & 1890 & $302(16.0 \%)$ & $1588(84.0 \%)$ & \\
\hline Argentine & 7 & $1(14.3 \%)$ & $6(85.7 \%)$ & \\
\hline Paraguayan & 21 & $4(19.0 \%)$ & $17(81.0 \%)$ & \\
\hline Italian & 597 & $157(26.3 \%)$ & 440 (73.7\%) & $<0.05$ \\
\hline Portuguese & 87 & $14(16.1 \%)$ & $73(83.9 \%)$ & \\
\hline Spanish & 37 & $6(16.2 \%)$ & $31(83.8 \%)$ & \\
\hline German & 217 & $66(30.4 \%)$ & $151(69.6 \%)$ & $<0.05$ \\
\hline Polish & 96 & $16(16.7 \%)$ & 80 (83.3\%) & \\
\hline Japanese & 17 & $1(5.9 \%)$ & $16(94.1 \%)$ & \\
\hline Other & 77 & $6(7.8 \%)$ & 71 (92.2\%) & \\
\hline Internal migration ${ }^{\mathrm{C}}$ & 3005 & & & \\
\hline North & 60 & $11(18.3 \%)$ & 49 (81.7\%) & \\
\hline Northeast & 101 & $11(10.9 \%)$ & $90(89.1 \%)$ & \\
\hline Middle West & 60 & $11(18.3 \%)$ & $49(81.7 \%)$ & \\
\hline Southeast & 194 & 15 (7.7\%) & 179 (92.3\%) & \\
\hline South & 2590 & $522(20.2 \%)$ & 2068 (79.8\%) & $<0.05$ \\
\hline Internal migrationd & 2497 & & & \\
\hline Paraná & 2102 & 394 (18.7\%) & 1708 (81.3\%) & \\
\hline Santa Catarina & 176 & 34 (19.3\%) & $142(80.7 \%)$ & \\
\hline Rio Grande do Sul & 219 & $81(37.0 \%)$ & $138(63.0 \%)$ & $<0.05$ \\
\hline
\end{tabular}

${ }^{a} \mathrm{~N}=$ total number of pregnant women for whom each result was available; ${ }^{b} \mathrm{x} M W=$ times minimum wage; Cinternal migration within Brazilian regions; dinternal migration within Southern states.

Table 3. Multivariate analysis of the parameters associated with hepatitis B virus markers.

\begin{tabular}{|c|c|c|c|c|c|}
\hline Variable & $\begin{array}{l}\text { Estimated } \\
\text { parameter }\end{array}$ & $\begin{array}{l}\text { Standard } \\
\text { error }\end{array}$ & $P$ & $\begin{array}{l}\text { Odds } \\
\text { ratio }\end{array}$ & $\begin{array}{l}95 \% \text { Confidence } \\
\text { interval }\end{array}$ \\
\hline Age (years) & 0.076 & 0.008 & $<0.0001$ & 1.079 & $1.062-1.097$ \\
\hline Color (black/others) & 0.612 & 0.175 & 0.0005 & 1.845 & $1.309-2.600$ \\
\hline $\begin{array}{l}\text { Family origin (Italian and } \\
\text { German/others) }\end{array}$ & 0.667 & 0.116 & $<0.0001$ & 1.949 & $1.553-2.446$ \\
\hline $\begin{array}{l}\text { Internal migration from South region states } \\
\text { (Rio Grande do Sul/Paraná and Santa Catarina) }\end{array}$ & 0.582 & 0.166 & 0.006 & 1.789 & $1.286-2.489$ \\
\hline Intercept & -3.590 & 0.226 & $<0.0001$ & 0.028 & \\
\hline
\end{tabular}


were associated with serological hepatitis B markers. For age, each year had an odds ratio of 1.079 while for the other variables selected by the model, the odds ratio were always higher than 1.7. Other variables such as educational level, family income and internal migration from other Brazilian regions were not associated with hepatitis $\mathrm{B}$ markers, probably because they are strongly related to the selected variables.

\section{Discussion}

Most of the available data on HBV prevalence are obtained from candidate blood donors since a large number of samples can be easily obtained at relatively low cost. Nevertheless, many biases are found in this population since it includes mostly young healthy adults from urban areas and some individuals donate blood to verify if they are carrying any blood-transmitted disease taking advantage of the anonymous condition (16). Furthermore, blood donation campaigns can be focused on special populations such as armed force recruits (17). In most of these studies, there is no detailed analysis of the population since no data concerning age, social class, color, educational level, ancestry, or origin are available.

Variable frequencies in HBV infection might be found in the same geographical area (18). Indeed, we found that the frequency of serological HBV markers is widely variable in different counties of Paraná State. In Cascavel, Foz do Iguaçu and Francisco Beltrão, the prevalence of $\mathrm{HBV}$ markers in pregnant women was found to be of intermediate-endemicity level, while a low-endemicity level was observed in Curitiba, Londrina, Maringá, and Paranaguá.

Five samples $(0.2 \%)$ showed an isolated HBsAg result, with an OD/CO ratio higher than 4.0, indicating that these results were not false-positive ones. Most of these results were obtained in Francisco Beltrão, where the highest prevalence of HBV markers was found. One possible explanation for this serological profile is an ongoing seroconversion. Isolated anti-HBc profiles were also more frequent in Francisco Beltrão (8.6\%), Cascavel (5.4\%), and Foz do Iguaçu (5.3\%), where the highest prevalence of HBV markers was found $(38.5,24.0$, and $24.6 \%$, respectively).

The frequency of isolated anti-HBs was used to evaluate vaccination coverage. This pattern was found in $7.7 \%$ pregnant women and was higher in Francisco Beltrão (17.3\%) and Cascavel (12.5\%), where hepatitis B vaccination was started in 1998. In Foz do Iguaçu, isolated anti-HBs was found in $4.9 \%$ of the pregnant women studied, probably reflecting an important migration of nonvaccinated people to this county. It is noteworthy that in 5 of the 7 counties analyzed only about $5 \%$ of the pregnant women were protected against HBV infection, as attested by their serological pattern of isolated antiHBs positivity. Furthermore, pregnant women without any positive serological HBV marker comprised $73.7 \%$ of the population studied, implying that HBV vaccination needs to be reinforced in Paraná State.

In the present study, the prevalence of serological HBV markers increased with age, supporting the idea that HBV transmission in these areas was mainly by the sexual or parenteral route, as previously suggested (5). On the other hand, in intermediate prevalence areas, the vertical transmission route cannot be ruled out.

Similar to data previously reported in the United States (19,20), HBV marker prevalence in Paraná State was higher in black women. This finding might be related to a higher prevalence of HBV infection among the first black inhabitants that settled in Paraná State. Also, the low-socioeconomic level found in the black population might be related to higher exposure to HBV transmission risk factors.

The highest prevalence among black women was observed in Francisco Beltrão. 
This county exhibited the lowest human development index, the highest number of illiterate inhabitants, the lowest family income, and the lowest number of dwellings with adequate sewage disposal (21).

East Asia is known as an intermediate HBV prevalence area (5), but only one pregnant woman of Japanese family origin was $\mathrm{HBsAg}$ and anti-HBc positive in the present study. Few pregnant women of Asian descent were analyzed in our study, even though there was an important immigration from Japan to Northern Paraná State. The reason is that this population did not look for public health services where our population was recruited. Most pregnant women of Asian ancestry look for private medical services, especially in Maringá and Londrina (22).

As expected, HBV marker prevalence and family income level were inversely correlated in Paraná State. This was also observed in Manaus, Porto Alegre, Rio de Janeiro, Belo Horizonte, Goiânia, and Fortaleza $(10,16,23-25)$.

Curitiba was the county where the lowest HBV marker prevalence was observed, probably because this county presented the highest salubrity and human development indexes and family income rate (22). The highest prevalence of HBV markers was found in low-income classes, especially in Francisco Beltrão, Foz do Iguaçu and Cascavel. These counties had the lowest salubrity and human development indexes, as well as the highest levels of inequality in income distribution. These indexes were even more pronounced in Francisco Beltrão, where the highest prevalence of HBV markers was found. According to previous results (19), higher levels of hepatitis B endemicity were found in areas with lower socio-economical levels.

If we consider only individuals of foreign ancestry, then pregnant women of German and Italian ascendance showed the highest prevalence of HBV markers. Data from Germany show low HBV prevalence, while in Italy some areas show intermediate preva- lence (5). An important German and Italian immigration took place during the colonization of Paraná State, West and Southwest regions, where Cascavel, Foz do Iguaçu, and Francisco Beltrão are located (26). Some of these immigrants still live in semi-isolated communities. Probably, the virus currently present in these regions came with these immigrants and their lifestyle maintained the intermediate $\mathrm{HBV}$ prevalence, as they mostly establish contact inside their communities.

When the HBV marker prevalence was analyzed considering the origin of the families from the major Brazilian regions in a univariate analysis, a higher prevalence was found for families that came from the South region of Brazil. Considering the three states in the South region, multivariate analysis showed that HBV marker prevalence was higher among families originating from Rio Grande do Sul State, especially in Francisco Beltrão, Cascavel and Foz do Iguaçu. Rio Grande do Sul is considered to be a lowprevalence area, but it is noteworthy that most studies have been carried out in Porto Alegre, its capital city. More studies analyzing HBV prevalence in different areas of this state should be carried out. For example, no data are available for areas near Santa Catarina and Paraná States, in the Northwest of Rio Grande do Sul where an important immigration from Germany and Italy occurred during the last century and some populations share the same features as populations from the other two states.

HBV serological marker data for Paraná State generally pointed to a low prevalence, but intermediate prevalence was observed in Cascavel, Foz do Iguaçu and Francisco Beltrão. These three counties received the largest number of families from Santa Catarina and Rio Grande do Sul and most of these migrants are of German or Italian ancestry. This finding probably indicates that HBV infection in Southwestern Paraná was brought by immigrants that arrived in this area at the beginning of the last century. 


\section{Acknowledgments}

We are deeply grateful to Dr. Suzane
Silbert (Hospital Israelita Albert Einstein) for a critical review of this manuscript.

\section{References}

1. Maynard JE. Hepatitis B: global importance and need for control. Vaccine 1990; 8 (Suppl): S18-S20.

2. Kane M. Global programme for control of hepatitis B infection. Vaccine 1995; 13 (Suppl 1): S47-S49.

3. Fay $\mathrm{OH}$. Hepatitis B in Latin America: epidemiological patterns and eradication strategy. The Latin American Regional Study Group. Vaccine 1990; 8 (Suppl): S82-S92.

4. Carrilho FJ, Corrêa MCJM. Magnitude of hepatitis B and C in Latin America. In: Schinazi RF, Sommadossi JP, Thomas HC (Editors), Therapies for viral hepatitis. Atlanta: International Medical Press; 1998. p 25-34.

5. Margolis HS, Alter MJ, Hadler SC. Hepatitis B: evolving epidemiology and implications for control. Semin Liver Dis 1991; 11: 84-92.

6. Souto FJD, Fontes CJF, Gaspar AMC. Outbreak of hepatitis B virus in recent arrivals to the Brazilian Amazon. J Med Virol 1998; 56: 4-9.

7. Ferreira CRB, Yoshida CFT, Mercadante LAC, Gomes DF, Oliveira $\mathrm{JM}$, França MS, et al. Immunization against hepatitis B in children from endemic zone: evaluation of the antibody response against the DNA recombinant vaccine (Engerix B-20 mcg). Rev Inst Med Trop Sao Paulo 1993; 35: 89-92.

8. Miranda LVG, Passos ADC, Figueiredo JFC, Gaspar AMC, Yoshida CFT. Marcadores sorológicos de hepatite $B$ em indivíduos submetidos a exames de sangue em unidades de saúde. Rev Saude Publica 2000; 34: 286-291.

9. Vasconcelos HCFF, Yoshida CFT, Vanderborght BOM, Schatzmayr HG. Hepatitis B and C prevalences among blood donors in the South Region of Brazil. Mem Inst Oswaldo Cruz 1994; 89: 503-507.

10. Clemens SAC, Fonseca JC, Azevedo T, Cavalcanti A, Silveira TR, Castilho MC, et al. Soroprevalência de hepatite A e hepatite B em quatro centros no Brasil. Rev Soc Bras Med Trop 2000; 33: 1-10.

11. Treitinger A, Spada C, Ferreira LA, Neto MS, Reis M, Verdi JC, et al. Hepatitis B and hepatitis C prevalence among blood donors and HIV-1 infected patients in Florianópolis - Brazil. Braz $J$ Infect Dis 2000; 4: 192-196.

12. Carvalho SP, Dias SLNG. Estudo comparativo da taxa de incidência de sífilis, doença de Chagas, hepatites B e C, HIV e HTLV, em doadores de sangue por região do Paraná. Rev Bras Anal Clin 1995; 27: 77-82.

13. Parra FC, Amado RC, Lambertucci JR, Rocha J, Antunes CM, Pena SD. Color and genomic ancestry in Brazilians. Proc Natl Acad Sci U $S$ A 2003; 100: 177-182.

14. Dean AG, Dean JA, Coulombier D, Brendel KA, Smith DC, Burton
$\mathrm{AH}$, et al. Epi Info, Version 6.04: a word processing database and statistics program for public health on IBM-compatible microcomputers. [Computer program]. Atlanta: Centers of Disease of Control and Prevention; 1998.

15. Statistical Package for Social Sciences (SPSS). [Computer program]. Chicago: SPSS Inc.; 2006.

16. Silveira TR, da Fonseca JC, Rivera L, Fay OH, Tapia R, Santos JI, et al. Hepatitis B seroprevalence in Latin America. Rev Panam Salud Publica 1999; 6: 378-383.

17. Focaccia R, Conceição OJG, Sette Jr H, Sabino EC, Bassit L, Nitrin $\mathrm{DR}$, et al. Estimated prevalence of viral hepatitis in the general population of the municipality of São Paulo, measured by a serologic survey of a stratified, randomized and residence-based population. Braz J Infect Dis 1998; 2: 269-284.

18. Bensabath G, Boshell J. Presence of Australian (Au) antigen in population groups of the interior of the State of Amazonas, Brazil. Rev Inst Med Trop Sao Paulo 1973; 15: 284-288.

19. Alter MJ, Hadler SC, Margolis HS, Alexander WJ, Hu PY, Judson $\mathrm{FN}$, et al. The changing epidemiology of hepatitis $\mathrm{B}$ in the United States. Need for alternative vaccination strategies. JAMA 1990; 263: 1218-1222.

20. Goldstein ST, Alter MJ, Williams IT, Moyer LA, Judson FN, Mottram $\mathrm{K}$, et al. Incidence and risk factors for acute hepatitis $\mathrm{B}$ in the United States, 1982-1998: implications for vaccination programs. J Infect Dis 2002; 185: 713-719.

21. IBGE - PNUD - Instituto de Pesquisa Econômica Aplicada - IPEA. Atlas do desenvolvimento humano no Brasil. Brasília: Fundação João Pinheiro - FJP; 1998.

22. Governo do Estado do Paraná. Etnias. http://www.pr.gov.br/etnias.

23. Cardoso DDP, Faria EL, Azevedo MSP, Queiroz DAO, Martins $\mathrm{RMB}$, Souza TT, et al. Soroepidemiologia para o vírus da hepatite $B$ (VHB) em gestantes/parturientes e sua transmissão para recémnascidos em Goiânia-GO. Rev Soc Bras Med Trop 1996; 29: 349353.

24. Andrade CA, Lima-Martins MVC, Costa JO, Ribeiro DA, Andrade AMC, Gonçalves RC, et al. Soroprevalência do HIV-1/2, HTLV-I/II e hepatites B e C em parturientes da Maternidade Odete Valadares, Belo Horizonte, Minas Gerais. Rev Bras Patol Trop 1999; 28: 41-48.

25. Tanaka J. Hepatitis B epidemiology in Latin America. Vaccine 2000; 18 (Suppl 1): S17-S19.

26. Strozzi JB. SUS Pense: uma reflexão epidemiológica sobre o SUS e outras aplicações acadêmicas. Londrina: CEBES; 1997. 